\title{
Soil microbial and nutrient dynamics in a wet Arctic sedge meadow in late winter and early spring
}

\author{
Kate A. Edwards, Jennifer McCulloch, G. Peter Kershaw, Robert L. Jefferies
}

\begin{abstract}
$\underline{\text { Abstract }}$
Microbial activity is known to continue during the winter months in cold alpine and Arctic soils often resulting in high microbial biomass. Complex soil nutrient dynamics characterize the transition when soil temperatures approach and exceed $0{ }^{\circ} \mathrm{C}$ in spring. At the time of this transition in alphine soils microbial biomass declines dramatically together with soil pools of available nutrients. This pattern of change characterizes alpine soils at the winter-spring transition but whether a similar pattern occurs in Arctic soils, which are colder, is unclear. In this study amounts of microbial biomass and the availability of carbon $(\mathrm{C})$, nitrogen $(\mathrm{N})$ and phosphorus $(\mathrm{P})$ for microbial and plant growth in wet peaty soils of an Arctic sedge meadow have been determined across the winter-spring boundary. The objective was to determine the likely causes of the decline in microbial biomass in relation to temperature change and nutrient availability. The pattern of soil temperature at depths of $5-15 \mathrm{~cm}$ can be divided into three phases: below $10^{\circ} \mathrm{C}$ in late winter, from 7 to $0^{\circ} \mathrm{C}$ for 7 weeks during a period of freeze-thaw cycles and above $0{ }^{\circ} \mathrm{C}$ in early spring. Peak microbial biomass and nutrient availability occurred early in the freezethaw phase. Subsequently, a steady decrease in inorganic $\mathrm{N}$ occurred, so that when soil temperatures rose above $0{ }^{\circ} \mathrm{C}$, pools of inorganic nutrients in soils were very low. In contrast, amounts of microbial C and soluble organic $\mathrm{C}$ and $\mathrm{N}$ remained high until the end of the period of freeze-thaw cycles, when a sudden collapse occurred in soluble organic $\mathrm{C}$ and $\mathrm{N}$ and in phosphatase activity, followed by a crash in microbial biomass just prior to soil temperatures rising consistently above $0{ }^{\circ} \mathrm{C}$. Following this, there was no large pulse of available nutrients, implying that competition for nutrients from roots results in the collapse of the microbial pool.
\end{abstract}

\section{Introduction}

Strong seasonal dynamics shape northern ecosystems; growing seasons are short, winters are cold, and soils remain frozen for most of the year, limiting decomposition and nutrient turnover (Shaver and Chapin, 1980; Chapin and Shaver, 1985; Giblin et al., 1991; Nadelhoffer et al., 1991; Jonasson, 1992). Although air and soil temperatures in the Arctic in mid-winter are well below $10^{\circ} \mathrm{C}$, where a snowpack is present in early and late winter, the soil is insulated so that temperatures beneath the snow rarely fall below $10^{\circ} \mathrm{C}$ and freeze-thaw events are frequent at these times. Although bulk soil water freezes just below $0{ }^{\circ} \mathrm{C}$, liquid water films remain around soil particles, at least down to temperatures of $8{ }^{\circ} \mathrm{C}$ (Romanovsky and Osterkamp, 2000; Price and Sowers, 2004). In spite of these sub-zero temperatures, microorganisms can remain physiologically active if unfrozen water is available (Coxson and Parkinson, 1987; Rivkina et al., 2000; Mikan et al., 2002). Substantial microbial activity has been recorded in alpine and Arctic soils in winter, even at temperatures of $5{ }^{\circ} \mathrm{C}$ or lower (Clein and Schimel, 1995; Zimov et al., 1996; Hobbie and Chapin, 1996; Brooks et al., 1996, 1998; Oechel et al., 1997; Fahnestock et al., 1998; Jones et al., 1999; Welker et al., 2000). If soil temperatures fall below $10^{\circ} \mathrm{C}$, as occurs in mid-winter, microbial biomass declines rapidly (Mikan et al., 2002). Hence, microbes can remain active and 
contribute significantly to the annual nutrient budget during early and late winter in an Arctic setting and throughout much of the winter in alpine regions where temperatures are not as extreme as those in the Arctic (Schimel et al., 2004; Schmidt and Lipson, 2004).

This current paradigm for soil microbial activity in winter comes largely from studies in the Colorado alpine tundra zone (Brooks et al., 1998; Lipson et al., 2000; Lipson et al., 2002; Schadt et al., 2003; Schmidt and Lipson, 2004). As described by Schmidt and Lipson (2004), plant and microbial growth during summer often deplete soils of available nitrogen. Decomposition of plant litter in the fall and early winter results in a release of available $N$ and C substrates in soil (Robinson et al., 1997), which supports microbial growth during the cold season. The fungal/bacterial ratio is apparently high in winter but in summer the ratio decreases, at least in alpine sites (Lipson et al., 2002; Schadt et al., 2003). Microbial biomass reaches an annual peak toward the end of the cold season, followed by a decline at the winter-spring transition, in part, caused by a shortage of C substrates (Lipson et al., 2000, 2002). Coincident with this decline in microbial biomass is a release of available soil $\mathrm{N}$ which peaks in late winter and decreases in early spring (Brooks et al., 1998). Much of this pulse of available $\mathrm{N}$ is presumed to come from the lysis of cells of the late winter microbial flora that are nutrientlimited and intolerant of freeze-thaw events, although some nutrients may be released from melting snow and plant and animal necromass. In experimental studies, a single freeze-thaw event kills up to $50 \%$ of the viable soil microbes (Soulides and Allison, 1961; Skogland et al., 1988; DeLuca et al., 1992). However, Lipson and Monson (1998) and Lipson et al. (2000) noted that microbial biomass was unaffected by single or multiple moderate freeze-thaw events in alpine meadows. Likewise, Grogan et al. (2004) reported that experimental periods of moderate freeze-thaw fluctuations appeared to have only a minor influence on the annual pattern of $C$ and nutrient dynamics in seasonally cold sub-Arctic soils. Nutrients released from the cells of the senescing microbes can be utilized by surviving microbial flora, but additional freeze-thaw cycles can lead to a steep decline of the cold-adapted microbial population (Soulides and Allison, 1961; Skogland et al., 1988; DeLuca et al., 1992). This release of nutrients represents the largest single annual input of available $\mathrm{N}$ into these cold soils and is mostly absorbed by plants for summer growth (Jaeger et al., 1999; Lipson et al., 1999, 2000). Although it is known that some roots can take up $\mathrm{N}$ under the snowpack in Arctic sites (Bilbrough et al., 2000), it is unclear whether similar complex nutrient dynamics occur in Arctic soils as in alpine soils (Schimel and Mikan, 2005).

The availability of exchangeable $\mathrm{N}$ and $\mathrm{P}$ is low in Arctic organic wetland soils (Shaver and Chapin, 1980; Ngai and Jefferies, 2004). The combination of a short growing season, low soil temperatures and nutrient-poor environments limits nutrient availability and constrains microbial and plant growth. Longer, colder winters, or shallower snow cover in the Arctic could leave soils too cold for significant microbial activity to take place (Bilbrough et al., 2000). In contrast, the higher winter temperatures, which are predicted to occur in the Arctic in response to climate change (Serreze et al., 2000), are likely to result in increased freeze-thaw cycles that will alter seasonal patterns of microbial biomass and biogeochemical processes controlling the availability of soil C, N and P. Given these scenarios and the lack of detailed studies of changes in microbial activity and resource availability at the winter-spring transition in Arctic soils, it is important to establish the sequence of soil events at this seasonal boundary and whether the alpine tundra model is fully applicable to Arctic soils. 
The transitional period occurring before and during the final thaw when microbial biomass declines and nutrients are released is recognized as a critical time of year for understanding annual nutrient cycles and plant-nutrient acquisition. This study was conducted in order to describe the sequence and timing of soil microbial and nutrient dynamics prior to the onset of the Arctic growing season. Elucidating the precise chronology of events at the winter-spring transition also should provide information on processes that control both the decline in microbial biomass and nutrient release ahead of spring allowing comparison of results with those from alpine regions.

\section{Materials and methods}

\subsection{Site description}

The study was conducted in calcareous fen mires (wet sedge meadows) within $2 \mathrm{~km}$ of the Churchill Northern Studies Centre, Churchill, Manitoba, Canada. (581440 1600N and 931490 0900W) located on the boundary between the sub-Arctic and the Arctic. The mires are dominated by extensive stands of Carex aquatilis, which is the most common type of plant community present in the coastal regions of the Hudson Bay Lowlands. Other vascular species present at a low frequency include Carex glareosa, C. gynnocrates, C. rariflora, Eriophorum angustifolium and Triglochin palustris.

Nomenclature of vascular plants follows Porsild and Cody (1980). The bryophyte flora is limited in abundance, but includes Tomentypnum nitens (Hedw.) Loeske, Drepanocladus revolvens (Sw.) Warnst. and Blepharostoma trichophyllum (L.) Dum.

The layer of organic-rich soil ( $\mathrm{pH} 6.5-7.5, \mathrm{C}, 37 \%$ and N, 2.5\% of dry weight) within stands of $\mathrm{C}$. aquatilis is about $25-30 \mathrm{~cm}$ deep and it overlies a mineral soil of sand, silt and fragmented limestone. The soil is a fibrous sedge peat which is highly humified. The entire coastal plain is typically wet and is characterised by the water table close to the surface for much of the summer (typically 4-8 g of water g1 dry soil at 5$15 \mathrm{~cm}$ depth), as a result of the presence of permafrost and the small change in elevation across the coastal zone of the Hudson Bay Lowland (c. $1 \mathrm{~m}$ change in elevation every 3-4 km). The bulk soils are usually anaerobic (Eh 50 to $+150 \mathrm{mv}$ at thaw and +100 to $+200 \mathrm{mv}$ in summer at $5-15 \mathrm{~cm}$ depth) and cold in the immediate post-thaw period. The presence of oxidized iron deposits in the rhizosphere in summer strongly suggests that oxygen movement via root aerenchyma of the sedges is occurring. The base-rich water drains in shallow vernal streams from the sedge meadows during and after thaw.

The average summer temperature (1932-1995) for July and August which represent the frost-free months is $11.8^{\circ} \mathrm{C}$ (Scott, 1996). Long-term weather data can be accessed from the Environment Canada web site (http://www.climate. weatheroffice.ec.gc.ca/Welcome_e.html). Snow can fall in any month but continuous snow cover usually does not occur until late October or early November. Spring thaw takes place in late May or early June in most years. Minimum winter air temperatures drop below $40{ }^{\circ} \mathrm{C}$ on occasions. 


\subsection{Soil temperatures}

A Campbell Scientific International CR10X was used to monitor air and soil temperatures. Type T thermocouples were used in conjunction with reference temperature thermistors on the logger wiring panel to measure temperatures at 5,10 , and $15 \mathrm{~cm}$ depths at a site adjacent to the experimental site. Overall reference junction accuracy was $00.1^{\circ} \mathrm{C}$ in the $33-48{ }^{\circ} \mathrm{C}$ range and $p 1.0^{\circ} \mathrm{C}$ in the $40-56{ }^{\circ} \mathrm{C}$ range (Campbell Scientific International, 1991). There were 288 readings each day (5 min scan interval) used to determine the mean daily, maximum and minimum values of soil temperatures within stands.

\subsection{Sample collection and processing}

In the snow-free season, six soil samples $(15 \mathrm{~cm} 15 \mathrm{~cm} 15 \mathrm{~cm})$ were collected between Carex shoots, two from each of three sites, which were separated from each other by a distance of at least $0.5 \mathrm{~km}$. Within a site, samples were taken from locations that were $50 \mathrm{~m}$ or more apart and the same location was not re-sampled during subsequent collections. In winter and during the transition period at the end of winter, frozen soil was removed with the use of an axe after removal of snow cover from designated locations within a site. It was not always possible to collect six samples in winter, and on occasions as few as 3 samples were collected, one from each site. The soils were placed in plastic bags and loaded into cooled containers with ice packs for transport to the laboratory. From May until August samples were processed on the same day as they were collected at the Churchill Northern Studies Centre, but on all other occasions (i.e. in autumn and winter) they were flown in a frozen state to Toronto, where they arrived the next day. The frozen soils were processed within 4 days of sampling but frequently sooner. As samples were collected from micro-sites (c. $20 \mathrm{~cm}$ in diameter) between stands of shoots, root density was not as high as beneath plants. The surface litter layer, small stones, roots and rhizomes were removed from soil before use, and fine fibrous roots also were extracted as far as possible.

Sub-samples used for analyses were representative of the entire soil sample which was mixed before use. Analyses included pore-water nutrient content (gloved-hand squeezing; dissolved organic N, C, Henry and Jefferies, 2002), exchangeable $\mathrm{N}(10 \mathrm{~g}$ f.w. of soil extracted in $50 \mathrm{ml}$ of $1 \mathrm{M} \mathrm{KCl}$, Wilson and Jefferies, 1996) and microbial C, N, P (225 g. f.w. of soil extracted in $50 \mathrm{ml}$ of $0.5 \mathrm{M} \mathrm{K} 2 \mathrm{SO} 4 \mathrm{using}$ a modified chloroform-fumigation extraction (Witt et al., 2000; Henry and Jefferies, 2003). The K2SO4 extraction of unfumigated soils also provided an extract of exchangeable P. All extracts were frozen in a freezer at $20^{\circ} \mathrm{C}$ at the Churchill Northern Studies Centre and remained frozen during the flight to Toronto and until further analysis.

\subsection{Sample collection and processing}

In the snow-free season, six soil samples $(15 \mathrm{~cm} 15 \mathrm{~cm} 15 \mathrm{~cm})$ were collected between Carex shoots, two from each of three sites, which were separated from each other by a distance of at least $0.5 \mathrm{~km}$. Within a site, samples were taken from locations that were $50 \mathrm{~m}$ or more apart and the same location was not re-sampled during subsequent collections. In winter and during the transition period at the end of winter, frozen soil was removed with the use of an axe after removal of snow cover from designated locations within a site. It was not always possible to collect six samples in winter, and on occasions as few as 3 samples were collected, one from each site. The soils were placed in plastic bags and loaded 
into cooled containers with ice packs for transport to the laboratory. From May until August samples were processed on the same day as they were collected at the Churchill Northern Studies Centre, but on all other occasions (i.e. in autumn and winter) they were flown in a frozen state to Toronto, where they arrived the next day. The frozen soils were processed within 4 days of sampling but frequently sooner. As samples were collected from micro-sites (c. $20 \mathrm{~cm}$ in diameter) between stands of shoots, root density was not as high as beneath plants. The surface litter layer, small stones, roots and rhizomes were removed from soil before use, and fine fibrous roots also were extracted as far as possible.

Sub-samples used for analyses were representative of the entire soil sample which was mixed before use. Analyses included pore-water nutrient content (gloved-hand squeezing; dissolved organic N, C, Henry and Jefferies, 2002), exchangeable $\mathrm{N}(10 \mathrm{~g}$ f.w. of soil extracted in $50 \mathrm{ml}$ of $1 \mathrm{M} \mathrm{KCl}$, Wilson and Jefferies, 1996) and microbial C, N, P (225 g. f.w. of soil extracted in $50 \mathrm{ml}$ of $0.5 \mathrm{M} \mathrm{K2SO4}$ using a modified chloroform-fumigation extraction (Witt et al., 2000; Henry and Jefferies, 2003). The K2SO4 extraction of unfumigated soils also provided an extract of exchangeable $P$. All extracts were frozen in a freezer at $20^{\circ} \mathrm{C}$ at the Churchill Northern Studies Centre and remained frozen during the flight to Toronto and until further analysis.

\subsection{Sample analyses}

The exchangeable inorganic $\mathrm{N}(\mathrm{NH} 4+, \mathrm{NO} 3$ ) was measured in filtered $1 \mathrm{M} \mathrm{KCl}$ soil extracts with the use of an auto-analyser (Technicon AAll, Tarrytown, NY). Nitrate was reduced to NO2 with cadmium before the colorimetric estimation. To estimate microbial $\mathrm{N}$, the total extractable $\mathrm{N}$ in filtered $0.5 \mathrm{M} \mathrm{K} 2 \mathrm{SO} 4$ fumigated and unfumigated soil extracts was oxidized with alkaline persulphate (Cabrera and Beare, 1993) and the nitrate was measured with the use of an auto-analyser after reduction to nitrite on cadmium columns. The difference in $\mathrm{N}$ between oxidized extracts of fumigated and unfumigated soils gave an estimate of microbial $N$. Soluble organic $N$ (DON) was measured from pore-water solution using the alkaline persulphate oxidation method described above. Microbial carbon in the oxidized extracts was determined as the difference between unfumigated and fumigated samples using the dichromate volumetric method to measure carbon (Nelson and Sommers, 1996). Interference with the C estimation from soil Fe 2+ in local soils of this type has been shown to be insignificant (Henry and Jefferies, 2003). Exchangeable phosphate was measured from unfumigated $0.5 \mathrm{M} \mathrm{K} 2 \mathrm{SO} 4$ extracts using the ammonium molybdate method (Ngai and Jefferies, 2004). The difference in phosphate between fumigated and unfumigated 0.5M K2SO4 extracts gave an estimate of soil microbial P. Acid and alkaline phosphatase activities were measured following Tabatabai and Dick (2002), using wet soil (1 g fresh weight) and $1 \mathrm{~h}$ incubation at $37^{\circ} \mathrm{C}$ in $4 \mathrm{ml}$ of buffer and $1 \mathrm{ml}$ of p-nitrophenylphosphate solution. This temperature was chosen in order to standardize conditions with other studies, although it may have led to denaturation of cold-adapted enzymes.

\subsection{Meltwater collection and analysis}

At one of the selected sites, a braided vernal stream carrying meltwater from a sedge meadow at a higher elevation flowed into the sedge meadow under study. The vegetation of the upper sedge meadow was very similar to that of the study site and it was dominated by $\mathrm{C}$. aquatilis. Inflows of $\mathrm{N}$ and 
$P$ in the stream water may contribute to the bulk soil nutrient pool during the winter-spring transition. In order to establish the magnitude of the flux, water was collected daily at midday from the first day of flow to the last day of sampling (12 May-2 June). The concentrations of soluble organic carbon and nitrogen, together with inorganic $\mathrm{N}$ and $\mathrm{P}$ in the stream water were analyzed as described above for soil water and exchangeable $\mathrm{P}$, in order to establish if changes in nutrient availability were occurring over the thaw period.

\subsection{Statistical analysis of the data}

We tested for differences between sampling dates using a univariate repeated measures ANOVA because there is insufficient replication within levels (sampling dates) to use a repeated measures MANOVA. The three sites were treated as subjects, and for sampling dates when more than one sample was taken from a site, values were averaged to ensure equal sample sizes. The Huynh-Feldt epsilon was used to adjust the degrees of freedom, thus correcting for sphericity in the data where necessary (von Ende, 2001). Multiple comparisons between sampling dates were performed using the Difference (reverse Helmert) test, in which each category is compared to the mean effect from all previous categories. Linear regression was used to test for trends over time in meltwater nutrient variables. All analyses were done in SPSS version 10 (SPSS Inc., 1999).

\section{Results}

\subsection{Soil temperatures during the winter-spring transition}

Soil temperature changes during the winter-spring transition can be partitioned into three phases (Fig. 1). During March 2005, which represented the first phase, soil temperatures were below $10{ }^{\circ} \mathrm{C}$ for the entire month at all soil depths $(5,10,15 \mathrm{~cm})$. The second phase started on 1 April and continued until about 19 May. This period was characterized by successive freeze-thaw cycles, during which time the maximum daily soil temperature at a depth of $5 \mathrm{~cm}$ (the fibrous rooting zone) in the adjacent site reached or exceeded $0{ }^{\circ} \mathrm{C}$ on 10 separate occasions in April and on 2 days it was above $5^{\circ} \mathrm{C}$. On 13 May, it exceeded $10{ }^{\circ} \mathrm{C}$. During the 7 weeks, soil temperatures at a depth of $5 \mathrm{~cm}$ ranged between 0 and $5{ }^{\circ} \mathrm{C}$ for most of the time. Soil temperatures at depths of 10 and $15 \mathrm{~cm}$ showed similar trends, although the diurnal range of values was dampened. Over the 7 weeks, much of the snow disappeared and the remainder was present as slush at the end of the period. An abrupt change to the third phase occurred immediately after 20 May when air and soil temperatures rose above $0{ }^{\circ} \mathrm{C}$, particularly at a depth of 5 $\mathrm{cm}$, and sites were snow-free by 23 May. Minimum air temperatures in early June were just below the freezing point for several days, but soils did not freeze (Fig. 1). Hence, dates at the winter-spring boundary marking transitions in the soil temperature regimes were 1 April and about 19 May. 

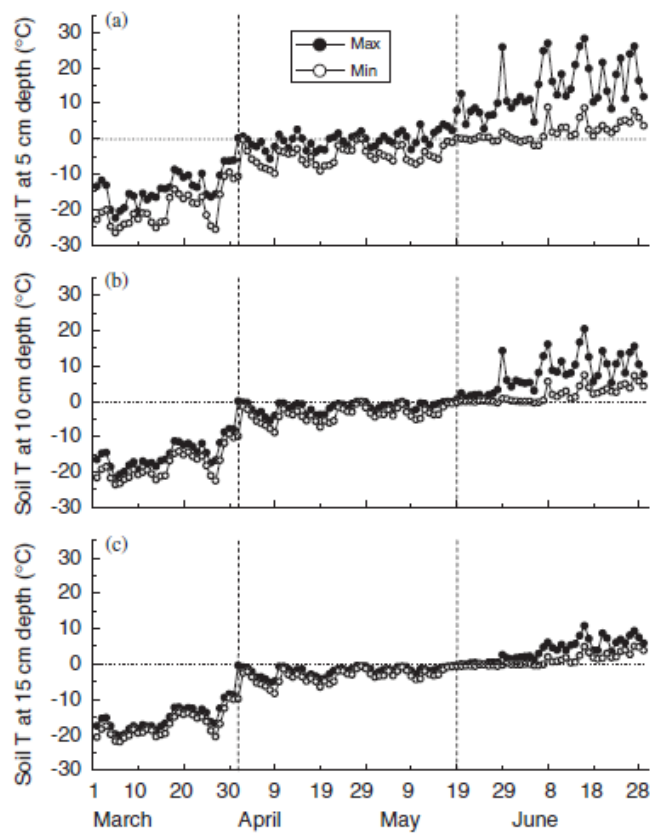

Fig. 1. Daily maximum and minimum soil temperature changes at depths of $5 \mathrm{~cm}(\mathrm{a}), 10 \mathrm{~cm}(\mathrm{~b})$, and $15 \mathrm{~cm}$ (c) during the winter-spring transition. Thermistor probes were connected to an automatic Campbell data logger to give readings every $15 \mathrm{~min}$. Probes were located within $500 \mathrm{~m}$ of two of the three sampling sites, near Churchill, Manitoba. Key transitions in temperature profiles on 1 April and 19 May are indicated with dotted lines.

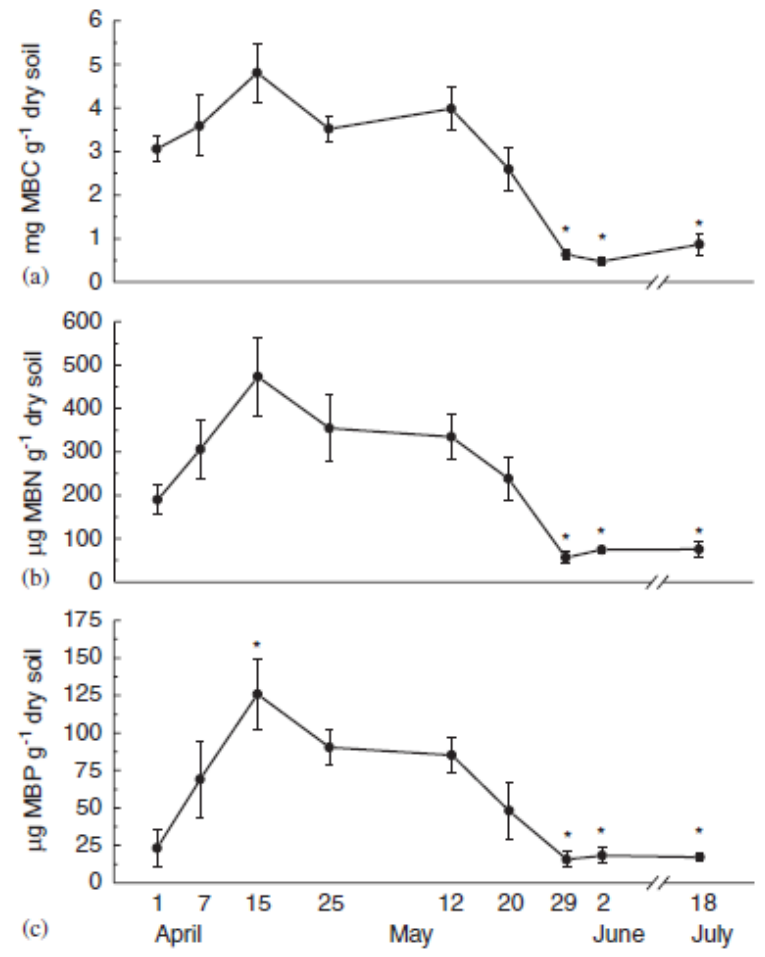

Fig. 2. Changes in the carbon (a), nitrogen (b), and phosphorus (c) of microbial biomass in calcareous mire soils at a depth of $5-15 \mathrm{~cm}$ dominated by stands of Carex aquatilis, near Churchill, Manitoba during the winter-spring transition. Means and standard errors are shown $(n=3-6)$, and values that are significantly different $(P=.05)$ from the mean of all previous measurements are indicated with an asterisk, as determined by the Difference (reverse Helmert) test.

\subsection{Microbial carbon, nitrogen and phosphorus}

Values of microbial biomass based on estimates of microbial carbon showed large significant seasonal changes (Fig. 2(a), Table 1). During the snow-free season in June and July 2005, microbial carbon was a quarter to one fifth of peak values in late winter and the summer values were similar to the corresponding values in the summer of 2004. (Microbial biomass rose in October 2004 to one third to one half of the late winter peak; data for 2004 not shown). The annual peak occurred in April when soil temperatures were between 0 and $5{ }^{\circ} \mathrm{C}$. Thereafter, there was a decline in biomass, particularly between 12 and 20 May, followed by a crash. An abrupt change in soil temperatures to values above 0 ${ }^{\circ} \mathrm{C}$ occurred about 19 May when microbial biomass was $54 \%$ of maximum values (20 May). Values of microbial $\mathrm{N}$ and $\mathrm{P}$ in soils (Fig. 2(b and c); Table 1 ) also showed significant peaks in mid-April, coincident with maximum values of microbial carbon. Subsequently, $\mathrm{N}$ and $\mathrm{P}$ values declined steadily and by 20 May estimates were $50 \%$ and $38 \%$ of peak values, respectively. There was a steep decline in biomass in the last 10 days of the month coincident with warmer soil temperatures, and by early June levels of microbial $\mathrm{C}, \mathrm{N}$ and $\mathrm{P}$ were similar to summer values. 
Table 1

Univariate repeated measures ANOVAs of microbial carbon (MBC), nitrogen (MBN) and phosphorus (MBP) and exchangeable ammonium, nitrate and phosphate ions, dissolved organic carbon (DOC) and nitrogen (DON), and acid and alkaline phosphatase (AcidPase and AlkPase) in organic calcareous mire soils near Churchill, Manitoba for different sample dates between 1 April and 18 July 2005

\begin{tabular}{|c|c|c|c|c|c|}
\hline Measure & Huyn-Feldt epsilon & Adjusted df & MS & $F$ & $P$ \\
\hline $\mathrm{MBC}$ & 1.000 & 8.00 & 62.563 & 10.338 & $.000^{*}$ \\
\hline Error & & 06.00 & 6.052 & & \\
\hline $\mathrm{MBN}$ & .525 & 4.20 & 817038.016 & 5.682 & $.016^{*}$ \\
\hline Error & & 8.39 & 143805.807 & & \\
\hline MBP & .475 & 3.80 & 64728.005 & 8.317 & $.007^{*}$ \\
\hline Error & & 7.60 & 7782.455 & & \\
\hline Exch $\mathrm{NH}_{4}^{+}$ & 1.000 & 8.00 & 1961.764 & 3.188 & $.023^{*}$ \\
\hline Error & & 16.00 & 615.395 & & \\
\hline Exch $\mathrm{NO}_{3}^{-}$ & 1.000 & 8.00 & 3.963 & 1.768 & .158 \\
\hline Error & & 16.00 & 2.242 & & \\
\hline DON & .233 & 1.63 & 100.847 & 7.599 & .061 \\
\hline Error & & 3.26 & 13.272 & & \\
\hline DOC & 1.000 & 8.00 & 11.277 & 14.780 & $.000^{*}$ \\
\hline Error & & 16.00 & .763 & & \\
\hline Exch P & .251 & 2.01 & .448 & 5.458 & .071 \\
\hline Error & & 4.02 & .08215 & & \\
\hline AcidPase & .718 & 5.75 & 70.853 & 4.047 & $.021^{*}$ \\
\hline Error & & 11.49 & 17.508 & & \\
\hline AlkPase & 1.000 & 8.00 & 43.066 & 4.003 & $.009^{*}$ \\
\hline Error & & 16.00 & 10.759 & & \\
\hline
\end{tabular}

The Huyn-Feldt epsilon was used to adjust the degrees of freedom.

MS $=$ mean squared (treatment and error); $F=F$ ratio for treatment; values labelled with '*' are significant at $P<0.05$.
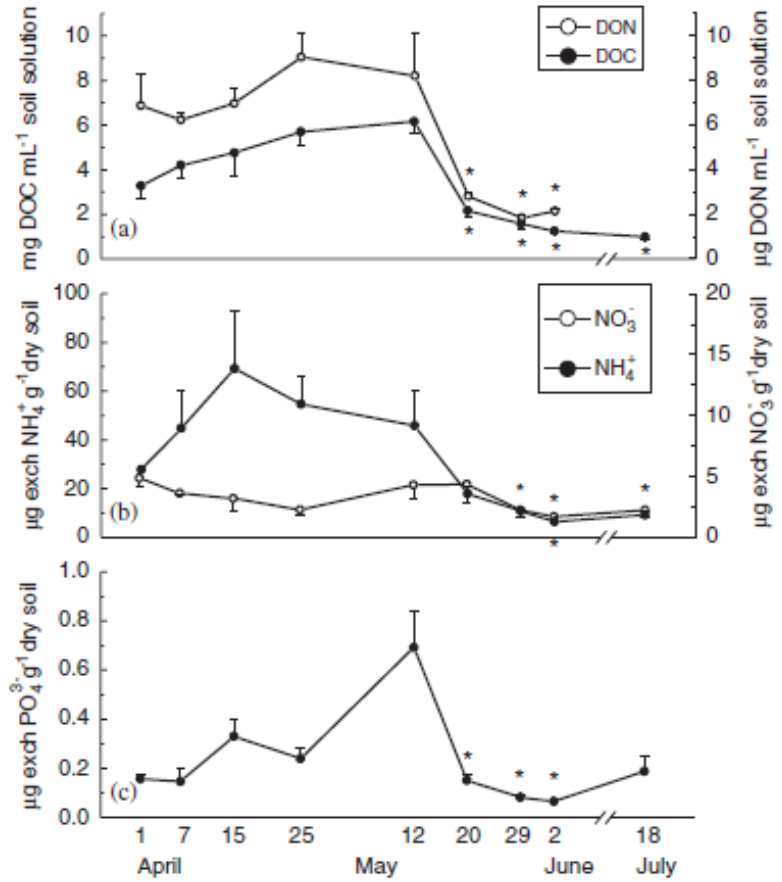
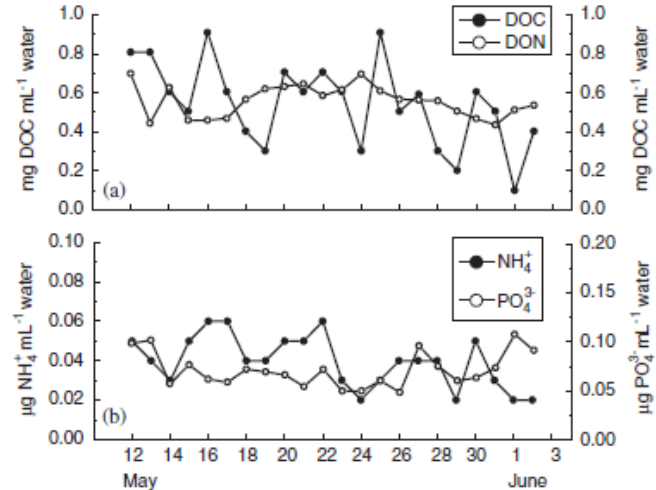

Fig. 4. The concentrations of soluble organic carbon and nitrogen (a) and soluble inorganic nitrogen and phosphorus as phosphate (b) in a small vernal run-off stream from a calcareous mire dominated by Carex aquatilis, near Churchill, Manitoba during the winter-spring transition.

Fig. 3. Amounts of soluble organic carbon and nitrogen (a), exchangeable ammonium and nitrate ions (b) and phosphate ions (c) in calcareous mire soils at a depth of 5-15 cm dominated by stands of Carex aquatilis, near Churchill, Manitoba during the winter-spring transition. Means and standard errors are shown $(n=3-6)$, and values that are significantly different $(P=.05)$ from the mean of all previous measurements are indicated with an asterisk, as determined by the Difference (reverse Helmert) test. 


\subsection{Exchangeable and/or soluble amounts of carbon, nitrogen and phosphorus in soils}

Amounts of soluble organic $\mathrm{C}$ and $\mathrm{N}$ in the soil solution of these wet sedge meadows increased steadily from early April until the end of the month, after which time values changed little until mid-May when there was a steep and significant decline in soluble $C$ and N (Fig. 3(a); Table 1). By early June, values of soluble $\mathrm{C}$ and $\mathrm{N}$ were about onequarter to one-third of peak values in April. In contrast, although amounts of exchangeable ammonium ions rose in early April, the rise was not sustained and there was a progressive decline to the very low levels of early June (Fig. 3(b), Table 1). Amounts of exchangeable ammonium resemble closely the observed patterns of microbial $\mathrm{N}$ over the same period. Concentrations of soluble nitrate were low throughout the entire period ( $00.05 \mathrm{mg} \mathrm{NO3-N} \mathrm{ml1} \mathrm{soil} \mathrm{water)} \mathrm{(Fig.} \mathrm{3(b),}$ Table 1). Amounts of exchangeable orthophosphate also declined from a mid-May peak to very low values by the end of May that were less than $10 \%$ of the peak levels (Fig. 3(c), Table 1).

\subsection{Concentrations of $\mathrm{C}, \mathrm{N}$ and $\mathrm{P}$ in vernal streams}

Meltwater entering one of the sedge meadow sites was collected daily and analyzed for changes in soluble organic $\mathrm{C}$ and $\mathrm{N}$, and for soluble inorganic $\mathrm{N}$ and $\mathrm{P}$ (Fig. 4(a and b)). In the case of N, organic $\mathrm{N}$ exceeded the combined inorganic fraction by an order of magnitude, but the absolute levels were low. Nitrate was very low at $0.01 \mathrm{mgml} 1$ of water (data not shown). There was no crash in available $\mathrm{N}$ (organic and inorganic) or $\mathrm{P}$ concentrations at the end of May, although inorganic $\mathrm{N}$ declined slightly from mid-May to early June (R2 1/4 0.26, po 0.01). Soluble organic carbon also declined throughout May and early June to about half of the value at the start of sampling when water flow commenced (R2 $1 / 4$ $0.24, \mathrm{p} 1 / 40.01)$.

\subsection{Acid and alkaline phosphatase activities}

Both acid and alkaline phosphatase activities, which were measured from early April until early June, had a similar pattern (Fig. 5(a and b), Table 1). Activity increased from early April onwards and peak activities were maintained until mid-May when a steep decline occurred. At the end of May, acid and alkaline phosphatase activities were very low, which was characteristic of the pattern in the summer.

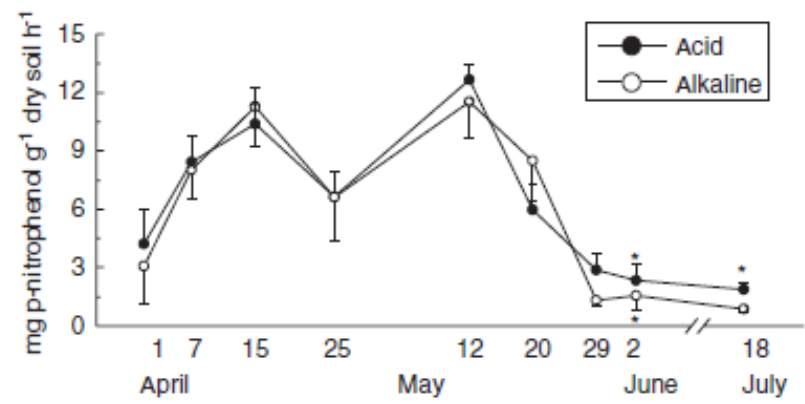

Fig. 5. Acid and alkaline phosphatase activities (measured at $37^{\circ} \mathrm{C}$ ) in calcareous mire soils at a depth of $5-15 \mathrm{~cm}$ dominated by stands of Carex aquatilis, near Churchill, Manitoba during the winter-spring transition. Means and standard errors are shown $(n=3-6)$, and values that are significantly different $(P=.05)$ from the mean of all previous measurements are indicated with an asterisk, as determined by the Difference (reverse Helmert) test. 


\section{Discussion}

\subsection{Freeze-thaw cycles and nutrient availability}

The higher soil temperatures, which rose from midwinter lows (below $10^{\circ} \mathrm{C}$ ) to between 7 and $0{ }^{\circ} \mathrm{C}$ during April and most of May 2005, allowed microbial growth to take place in this period characterized by freeze-thaw events. Temperature changes in soil at a depth of $5 \mathrm{~cm}$ were more closely coupled to air temperatures and showed greater amplitude between day and night values compared with similar changes at depths of 10 and $15 \mathrm{~cm}$. The freeze- thaw cycles are likely to lead to the downward percolation of melt water into the soil. Nutrient availability and microbial biomass increased during the first 2 weeks of April and peak biomass and availability of nutrients in soil occurred in mid-April, except for exchangeable $P$, which peaked in mid-May. The increase in resources probably represents the release of inorganic nutrients in free water in late winter and during spring thaw that had accumulated over winter, as a result of fragmentation of plant litter, cell lysis, leaching of nutrients from tissues and mineralization (Hobbie and Chapin, 1996). Taylor and Jones (1990) concluded that decomposition over the winter usually led to a loss of between $40 \%$ and $60 \%$ of the litter mass, based on the results from 17 studies. In addition to inorganic nutrients, pools of soluble organic $\mathrm{C}$ and $\mathrm{N}$ also rose in early April and much of this organic $\mathrm{C}$ and $\mathrm{N}$ was probably derived from the lysis of microbial necromass that had remained in a frozen state over the winter. In an experimental laboratory study of Alaskan tundra and taiga soils, the initial freeze-thaw cycle caused a flush of soil $\mathrm{C}$ and $\mathrm{N}$, but subsequent cycles led to a reduction in the decomposition rate and the total amounts of $\mathrm{C}$ and $\mathrm{N}$ mineralized (Schimel and Clein, 1996). This implies that the readily mineralized fraction was quickly depleted in these soils and that as a result, microbial activity declined, as shown by the fall in soil respiration rates. At the Churchill site there also was a steady decline in exchangeable inorganic $\mathrm{N}$ from mid-April onwards and the concentration of soluble $\mathrm{N}$ in the vernal stream also declined in May. These trends are consistent with the experimental results of Schimel and Clein (1996).

In contrast to the decrease in the availability of inorganic $\mathrm{N}$, concentrations of soluble organic carbon and nitrogen in the soils remained elevated until the crash which occurred after mid-May. In addition, acid and alkaline phosphatase activities were maintained until mid-May when a steep decline occurred. This suggests that the pool of soluble organic substrates included phosphate esters and that the demand for $\mathrm{P}$ by the microbial flora was at least partially met by the hydrolysis of these esters as the pool of inorganic $\mathrm{P}$ declined. However, amounts of soluble organic $\mathrm{N}$ relative to exchangeable ammonium ions were low, hence the supply of organic $\mathrm{N}$ appears to be insufficient to compensate completely for the decline in available inorganic $\mathrm{N}$. In spite of the decline in microbial biomass $\mathrm{N}$ and soluble $\mathrm{C}$ and $\mathrm{N}$ during the final stages of snow melt, there was no subsequent flush of inorganic $\mathrm{N}$, a similar finding to that of Brooks et al. (1998) from alpine regions. In their studies, although net $\mathrm{N}$ mineralization occurred in soil beneath snow in early spring, it was quickly followed by net immobilization of $\mathrm{N}$ once snow melt took place (Brooks et al., 1996). As Schmidt and Lipson (2004) have pointed out, the microbial community acts first as a sink for nutrients in late winter when snow cover prevails and then as a source of nutrients in early spring at the time of snow melt, but it appears that this source is rapidly depleted in both the studies of Brooks et al., (1996) and our study. 


\subsection{Plant uptake of available nitrogen}

The decline of biomass after snowmelt in alpine soils releases organic $\mathrm{N}$ that can be taken up by plants (Lipson et al., 1999). A similar situation occurs on the Cape Churchill Peninsula where free amino acid concentrations relative to ammonium concentrations were highest during the period of rapid plant growth in late spring (Henry and Jefferies, 2002). In a short-term (24 h) experimental field study using intact soil cores, the grass, Puccinellia phryganodes, incorporated $15 \mathrm{~N}$-labelled glycine, ammonium and nitrate ions in amounts which were $56 \%, 83 \%$, and $68 \%$, respectively of the comparable incorporation of these sources of $\mathrm{N}$ by soil microrganisms (Henry and Jefferies, 2003). Application of $15 \mathrm{NH} 4 \mathrm{Cl}$ to soil cores also indicated that plants are capable of incorporating the tracer very early in spring (Buckeridge, 2004). Uptake of different $\mathrm{N}$ sources by plants is known to be maximal at this stage of the season (Theodose et al., 1996; Jaeger et al., 1999), and Chapin and Bloom (1976) showed that the new roots of Eriophorum are capable of following the ice edge as the active layer develops and can absorb phosphate at very low temperatures (1-2 C).

\subsection{Microbial biomass}

The results indicate that dramatic changes occurred both in microbial biomass and resources over a period as little as 1 week to 10 days in the second half of May, just prior to the sustained rise in soil temperatures to above the freezing point in late May. This is similar to the decline in microbial biomass that occurred in dry alpine meadows where a decrease in microbial biomass took place before the snow had fully melted and soil temperatures were around $0{ }^{\circ} \mathrm{C}$ (Brooks et al., 1998). Hence, the decline in microbial biomass and in resources precedes the sustained temperature rise above the freezing point and the results strongly suggest that the lack of resource availability contributes to the crash. The sequence of nutrient availability over time, therefore, is initially a decline in exchangeable inorganic $\mathrm{N}$ from mid-April onwards, followed by a very large drop in soluble soil carbon and exchangeable $P$ from mid-May onwards that precedes a steep decline in microbial biomass at the end of May. However, the steepness of the declines implies that other drivers are forcing the changes. The most likely causes of the declines are: (a) competition for organic $\mathrm{C}$ and $\mathrm{N}$ from plant roots, which are known to take up amino acids directly from soil at low temperatures in Arctic systems (Chapin et al., 1993; Kielland, 1994, 1995; Henry and Jefferies 2003), (b) the lysis of microbial cells in response to transient temperatures above $0^{\circ} \mathrm{C}$ and (c) depletion of soil $\mathrm{N}$ and P. In laboratory experiments, Lipson et al. (2000) found that although soil microbial biomass was resistant to repeated fluctuations around $0{ }^{\circ} \mathrm{C}$, the winter microbial community was sensitive to soil temperatures that remained above the freezing point. In our study the microbial biomass crashed just prior to the soil temperatures remaining above $0{ }^{\circ} \mathrm{C}$, hence $15 \mathrm{~N}$ studies are required to examine in detail the competitive ability of plants to accumulate the tracer just prior to the bulk soils remaining above the freezing point. In addition, carbon and nitrogen sources need to be added to plots in the absence and presence of vegetation, in order to establish whether the microbial peak can be sustained in early spring at soil temperatures just above $0{ }^{\circ} \mathrm{C}$.

Although values of microbial biomass peaked in mid-April, microbial activity at that time is likely to be low. Recent studies in coastal marshes on the Cape Churchill Peninsula of activity based on the residence time of $15 \mathrm{~N}$ in the microbial biomass indicated that the residence time was about 100 days at 
the end of April 2003. This in sharp contrast to residence times of a few days in summer and early winter (October) when amounts of microbial biomass are substantially lower than values in late winter (Buckeridge, 2004). Similar low amounts of microbial biomass have been recorded in these wet sedge meadows in summer, but it is not known whether the turnover rates are faster than those in late winter. It is likely that the high microbial biomass values in late winter are linked to low microbial activity and that the reverse pattern occurs in summer. The microbial biomass values for $\mathrm{C}, \mathrm{N}$, and $\mathrm{P}$ continue to decline up to 29 May together and the $C: N$ ratio declines from about 13:1 in mid-April and May to 7:1 in early June. Whether this relates to a shift from a fungal-dominated microbial community feeding on necromass in late winter to a bacterial-dominated community in summer, dependent on root exudation, as appears to occur in alpine communities (Lipson et al., 2002; Schadt et al., 2003), is unknown.

\section{Conclusion}

The transitional period occurring before and during the final thaw, when microbial biomass and inorganic and organic pools of nutrients decline and plant growth commences, is recognized as a critical time of year for understanding annual nutrient cycles and plant-nutrient acquisition (Bardgett et al., 2005). This study indicates that large changes occurred in soil microbial and nutrient dynamics prior to the onset of the Arctic growing season. The results show close similarities to trends observed in alpine soils. However, the pattern does not appear to be identical to that from alpine soils, based on limited data. The more extreme mid-winter temperatures, the absence of a nutrient pulse in spring and the presence of the sedge community may account for the differences between the Arctic and alpine sites.

\section{Acknowledgments}

We thank Deborah Tam and Emma Horrigan for excellent assistance during this investigation. Dr. LeeAnn Fishback kindly collected soil samples on occasions in winter. We gratefully acknowledge the consultation and help from Dr. Diana Horton who identified the bryophytes. Dr. Paul Grogan and Dr. Hugh A. L. Henry provided valuable comments on an earlier version of this manuscript. The staff of the CNSC kindly provided logistic support. We are grateful to the Churchill Northern Studies Centre and the Department of Indian and Northern Affairs for financial and logistical support to K.E. We gratefully acknowledge comments and suggestions from reviewers and the Editor on an earlier version of this manuscript. The study was supported by a grant to R.L.J from NSERC.

\section{$\underline{\text { References }}$}

Bardgett, R.D., Bowman, W.D., Kaufmann, R., Schmidt, S.K., 2005. A temporal approach to linking aboveground and belowground ecology. Trends in Ecology and Evolution 20, 634-641.

Bilbrough, C., Welker, J., Bowman, W.D., 2000. Early spring nitrogen uptake by snow-covered plants: a comparison of arctic and alpine plant function under the snowpack. Arctic, Antarctic and Alpine Research 32, 404-411.

Brooks, P.D., Williams, M.W., Schmidt, S.K., 1996. Microbial activity under alpine snowpacks, Niwot Ridge, Colorado. Biogeochemistry 32, 93-113. 
Brooks, P.D., Williams, M.W., Schmidt, S.K., 1998. Inorganic nitrogen and microbial biomass dynamics before and during spring snowmelt. Biogeochemistry 43, 1-15.

Buckeridge, K.M., 2004. The allocation of inorganic nitrogen $(15 \mathrm{NH} 4+)$ to soil, microbial and plant biomass in an Arctic salt marsh. M.Sc.Thesis, University of Toronto, Ont.

Cabrera, M.L., Beare, M.H., 1993. Alkaline persulfate oxidation for determining total nitrogen in microbial biomass extracts. Soil Science Society of America Journal 57, 1007-1012.

Campbell Scientific, Canada. 1991. 10TCRT thermocouple reference instruction manual. Campbell Scientific, Canada, Edmonton.

Chapin III, F.S., Bloom, A., 1976. Phosphate absorption: adaptation of tundra graminoids to a low temperature, low phosphorus environment. Oikos 27, 111-121.

Chapin III, F.S., Shaver, G.R., 1985. Individualistic growth response of tundra plant species to environmental manipulations in the field. Ecology 66, 564-576.

Chapin III, F.S., Moilanen, L., Kielland, K., 1993. Preferential use of organic nitrogen for growth by a nonmycorrhizal arctic sedge. Nature 361, 150-153.

Clein, J.S., Schimel, J.P., 1995. Microbial activity of tundra and taiga soils at sub-zero temperatures. Soil Biology \& Biochemistry 19, 49-59.

Coxson, D.S., Parkinson, D., 1987. Winter respiratory activity in aspen woodland forest floor litter and soils. Soil Biology \& Biochemistry 19, 49-59.

DeLuca, T.H., Keeney, D.R., McCarty, G.W., 1992. Effect of freeze-thaw events on mineralization of soil nitrogen. Biology and Fertility of Soils 14, 116-120.

Fahnestock, J.T., Jones, M.H., Brooks, P.D., Walker, D.A., Welker, J.M., 1998. Winter and early spring CO2 efflux from tundra communities of northern Alaska. Journal of Geophysical Research-Atmospheres 103, 29023-29027.

Giblin, A.E., Nadelhoffer, K.J., Shaver, G.R., Laundre, J.A., McKerrow, A.J., 1991. Biogeochemical diversity along a riverside toposequence in arctic Alaska. Ecological Monographs 61, 415-435.

Grogan, P., Michelsen, A., Ambus, P., Jonasson, S., 2004. Freeze-thaw regime effects on carbon and nitrogen dynamics in sub-arctic heath tundra mesocosms. Soil Biology \& Biochemistry 36, 641-654.

Henry, H.A.L., Jefferies, R.L., 2002. Free amino acid, ammonium and nitrate concentrations in soil solutions of a grazed coastal marsh in relation to plant growth. Plant Cell and Environment 25, 665-675.

Henry, H.A.L., Jefferies, R.L., 2003. Plant amino acid uptake, soluble $\mathrm{N}$ turnover and microbial $\mathrm{N}$ capture in soils of a grazed Arctic salt marsh. Journal of Ecology 91, 627-636. 
Hobbie, S.E., Chapin III, F.S., 1996. Winter regulation of tundra litter carbon and nitrogen dynamics. Biogeochemistry 35, 327-338.

Jaeger, C.H., Monson, R.K., Fisk, M.C., Schmidt, S.K., 1999. Seasonal partitioning of nitrogen by plants and soil microorganisms in an alpine ecosystem. Ecology 80, 1883-1891.

Jonasson, S., 1992. Plant responses to fertilization and species removal in tundra related to community structure and clonality. Oikos 63, 420-429.

Jones, M.H., Fahnestock, J.T., Welker, J.M., 1999. Early and late winter CO2 efflux from Arctic tundra in the Kuparuk river watershed, Alaska, USA. Arctic, Antarctic and Alpine Research 31, 187-190.

Kielland, K., 1994. Amino acid absorption by arctic plants: implications for plant nutrition and nitrogen cycling. Ecology 75, 2373-2383.

Kielland, K., 1995. Landscape patterns of free amino acids in arctic tundra soils. Biogeochemistry $31,85-$ 98.

Lipson, D.A., Monson, R.K., 1998. Plant-microbe competition for soil amino acids in the alpine tundra: effects of freeze-thaw and dry-rewet events. Oecologia 113, 406-414.

Lipson, D.A., Schmidt, S.K., Monson, R.K., 1999. Links between microbial population dynamics and nitrogen availability in an alpine ecosystem. Ecology 80, 1623-1631.

Lipson, D.A., Schmidt, S.K., Monson, R.K., 2000. Carbon availability and temperature control the postsnowmelt baseline in alpine soil microbial biomass. Soil Biology \& Biochemistry 32, 441-448.

Lipson, D.A., Schadt, C.W., Schmidt, S.K., 2002. Changes in soil microbial community structure and function in an alpine dry meadow following spring snow melt. Microbial Ecology 43, 307-314.

Mikan, C.J., Schimal, J.P., Doyle, A.P., 2002. Temperature controls of microbial respiration in arctic tundra soil above and below freezing. Soil Biology \& Biochemistry 34, 1785-1795.

Nadelhoffer, K.J., Giblin, A.E., Shaver, G.R., Laundre, J.A., 1991. Effects of temperature and substrate quality on element mineralization in six arctic soils. Ecology 72, 242-253.

Nelson, D.W., Sommers, L.E., 1996. Total carbon, organic carbon, and organic matter. In: Sparks, D.L., Page, A.L., Helmke, P.A., Loeppert, R.H., Solanpour, P.N., Tabatabai, M.A., Johnston, C.T., Summer, M.E. (Eds.), Methods in Soil Analysis, Part 3: Chemical Methods. Soil Science Society of America, Madison, WI, pp. 961-1010.

Ngai, J.T., Jefferies, R.L., 2004. Nutrient limitation of plant growth and forage quality in Arctic coastal marshes. Journal of Ecology 92, 1001- 1010.

Oechel, W.C., Vourlitis, G., Hastings, S.J., 1997. Cold season CO2 emission from arctic soils. Global Biogeochemical Cycles 11, 163-172. 
Price, P.B., Sowers, T., 2004. Temperature dependence of metabolic rates for microbial growth, maintenance and survival. Proceedings of the National Academy of Sciences of the United States of America 101, 4631-4636.

Porsild, A.E., Cody, W.J., 1980. Vascular plants of continental Northwest Territories, Canada. National Museum, Ottawa, Ont.

Rivkina, E.M., Friedmann, E.I., McKay, C.P., Gilichinsky, D.A., 2000. Metabolic activity of permafrost bacteria below the freezing point. Applied and Environmental Microbiology 66, 3230-3233.

Robinson, C.H., Michelsen, A., Lee, J.A., Whitehead, S.J., Callaghan, T.V., Press, M.C., Jonasson, S., 1997. Elevated atmospheric $\mathrm{CO} 2$ affects decomposition of Festuca vivipara (L.) Sm. litter and roots in experiments simulating environmental change in two contrasting arctic ecosystems. Global Change Biology 3, 37-49.

Romanovsky, V., Osterkamp, T., 2000. Effects of unfrozen water on heat and mass transport processes in the active layer and permafrost. Permafrost and Periglacial Processes 11, 219-239.

Serreze, M.C., Walsh, J.E., Chapin, F.S., Osterkamp, T., Dyurgerov, M., Romanovsky, V., Oechel, W.C., Morison, J., Zhang, T., Barry, R.G., 2000. Observational evidence of recent change in the northern highlatitude environment. Climatic Change 46, 159-207.

Schadt, C.W., Martin, A.P., Lipson, D.A., Schmidt, S.K., 2003. Seasonal dynamics of previously unknown fungal lineages in tundra soils. Science 301, 1359-1361.

Schimel, J.P., Clein, J.S., 1996. Microbial response to freeze-thaw cycles in tundra and taiga soils. Soil Biology \& Biochemistry 28, 1061-1066.

Schimel, J.P., Bilbrough, C., Welker, J.A., 2004. Increased snow depth affects microbial activity and nitrogen mineralization in two Arctic tundra communities. Soil Biology \& Biochemistry 36, 217-227.

Schimel, J.P., Mikan, C., 2005. Changing microbial substrate use in Arctic tundra soils through a freezethaw cycle. Soil Biology \& Biochemistry 37, 1411-1418.

Schmidt, S.K., Lipson, D.A., 2004. Microbial growth under the snow: Implications for nutrient and allelochemical availability in temperate soils. Plant and Soil 259, 1-7.

Scott, P., 1996. Flora of Churchill, Manitoba. Department of Biological Sciences. University of Alberta, Edmonton, Alta.

Shaver, G.R., Chapin III, F.S., 1980. Response to fertilization by various plant growth forms in an Alaskan tundra: nutrient accumulation and growth. Ecology 61, 662-675.

Skogland, T., Lomeland, S., Goksoyr, J., 1988. Respiratory burst after freezing and thawing of soil: experiments with soil bacteria. Soil Biology \& Biochemistry 20, 851-856. 
Soulides, D.A., Allison, F.E., 1961. Effects of drying and freezing soils on carbon dioxide production, available mineral nutrients, aggregation, and bacterial populations. Soil Science 91, 291-298.

SPSS Inc., 1999. SPSS for Windows, Version 10. Chicago, Illinois 60606, USA.

Tabatabai, M.A., Dick, W.A., 2002. Enzymes in soil. In: Burns, R.G., Dick, R.P. (Eds.), Enzymes in the Environment: Activity, Ecology and Applications. Marcel Dekker, New York, pp. 567-596.

Taylor, B.R., Jones, H.G., 1990. Litter decomposition under snow cover in a balsam fir forest. Canadian Journal of Botany 68, 112-120.

Theodose, T.A., Jaeger, C.H., Bowman, W.D., Schardt, J.C., 1996. Uptake and allocation of N-15 in alpine plants: implications for the importance of competitive ability in predicting community structure in a stressful environment. Oikos 75, 59-66.

von Ende, C.N., 2001. Repeated-measures analysis: growth and other time dependent measures. In: Scheiner, S.M., Gurevitch, J. (Eds.), The Design and Analysis of Ecological Experiments. Chapman \& Hall, New York, pp. 134-157.

Welker, J.M., Fahnestock, J.T., Jones, M.H., 2000. Annual CO2 flux in dry and moist Arctic tundra: field responses to increases in summer temperatures and winter snow depth. Climate Change 44, 139-150.

Wilson, D.J., Jefferies, R.L., 1996. Nitrogen mineralization, plant growth and goose herbivory in an Arctic coastal ecosystem. Journal of Ecology 84, 841-851.

Witt, C., Gaunt, J.L., Galicia, C.C., Ottow, J.C.G., Neue, H.U., 2000. A rapid chloroform-fumigation extraction method for measuring soil microbial biomass carbon and nitrogen in flooded rice soils. Biology and Fertility of Soils 30, 510-519.

Zimov, S.A., Davidov, S.P., Voropaev, Y.V., Prosiannikov, S.F., Semiletov, I.P., Chapin, M.C., Chapin, F.S., 1996. Siberian CO2 efflux in winter as a CO2 source and cause of seasonality in atmospheric CO2.

Climatic Change 33, 111-120. 